\title{
Range of main species of phytophages and entomophages of cotton agrobiocenosis in lower reaches of the Zarafshan river.
}

\author{
$B$. Fayzullaev*, and $O$. Mirzamurodov \\ Samarkand State University, Department of Ecology and Life Safety, 140104 Samarkand, Uzbekistan
}

\begin{abstract}
Numerous arthropods have adapted to live in various biocenosis in the process of evolutionary transformation, especially under the influence of anthropogenic pressure, in particular cotton, which is widely distributed in Uzbekistan, especially in the lower reaches of the Zarafshan river. Among them there is a large group of phytophages, which causes substantial harm to cotton. It is also home to predatory and parasitic insects, entomophages, which are their effective regulators. The long-term impact of the anthropic factor on the complex of phytophages and entomophages in cotton agrobiocenosis could not but affect their vital activity. Meanwhile, previous studies did not fully open the nature of interaction of individual groups of arthropod animals and did not take into account the changes that occurred in the transformed natural environment. The aim of the research is to study the species composition of arthropods, to determine the main species of phytophages and entomophages, their ecology and biological principles for regulating their numbers in cotton agrobiocenosis.
\end{abstract}

\section{Introduction.}

Numerous arthropods in the process of evolutionary transformation, especially under the influence of anthropopression, have adapted to living in various biocenosis, in particular cotton, which is widely represented in Uzbekistan, especially in the lower reaches of the Zarafshan river. Among them, a large group of phytophages is represented, which causes substantial harm to cotton. It is also home to predatory and parasitic insects, entomophages, which are their effective regulators [1].

The long-term impact of the anthropic factor on the complex of phytophages and entomophages in cotton agrobiocenosis could not but affect their vital activity. Meanwhile, previous studies did not fully disclose the nature of the interaction of individual groups of arthropod animals and did not take into account the changes that occurred in the transformed natural environment [2].

The mentioned provides a basis for studying the ecology features of the main species of phytophages and entomophages in cotton agrobiocenosis in the lower reaches of the Zarafshan river, which play a certain biological role under these conditions. At the same time, in order to improve the natural environment, research on the selection of environmentally friendly drugs on a microbiological basis is of significant importance, to which we also paid due attention, using the latest achievements of domestic and foreign scientists [3].

\footnotetext{
* Corresponding author: boymurodov1971@mail.ru
} 
The aim of the research is to study the species composition of arthropods, to determine the main species of phytophages and entomophages, their ecology and biological principles for regulating their numbers in cotton agrobiocenosis.

\section{Material and research methods}

The studies were carried out in 2017-2020 in agrobiocenosis of cotton in the lower reaches of the Zarafshan River. Stationary work was carried out in cotton agrobiocenosis in Jondor district of Bukhara region.

Experimental observations were made annually for 4 complete generations of cotton moth, 10-14 complete generations of spider mite and cotton aphids. There were 3,973 specimens of cotton moth caterpillars under laboratory observation, from which 2,315 butterfly specimens were bred. More than 27 thousand specimens of eggs and caterpillars hatched from them were observed in insectarium conditions.

To determine the species composition of phytophages and entomophages, we collected more than 35 thousand specimens of arthropods.

For faunistic and phenological research in field and laboratory experimental work we used generally recognized methods of V.V.Yakhontov [4]; N.N.Bogdanov-Katkov [5]; M.S. Gilyarov [6]; F.M.Uspenskiy[7]; K.I. Larchenko [8]; R.A.Alimdjanov [1], S.N. Alimekhamedov [9] etc.

To clarify the species composition of the parasites of gnawing and ground moths, we carried out growing in cages of caterpillars of different ages collected in nature, where the pupae of the pests were placed.

The species composition of parasites in cotton aphids was studied by collecting mummified individuals and breeding parasites in laboratory conditions [10].

In order to identify the population of cotton by the main phytophages and entomophages, to study the seasonal dynamics of the number of aphids, spider mites and their entomophages occurring in agrobiocenosis from the emergence of cotton seedlings to harvesting, we examined 20 plant samples every five days on plots of up to 5 hectares along the field diagonal (in a sample of 5 plants).

In order to detect cotton moth and other ground moths, 100 plants were examined in each field, located at equal distances along two diagonals. The number of eggs and caterpillars was taken into account [8].

\section{Results}

In the agrobiocenosis of cotton in the lower reaches of the Zarafshan River, 63 arthropod species belonging to 10 orders, 25 families, and 52 genera were identified. Among them, phytophages are represented by 31 species, and entomophages - 32 (Table 1).

Table 1. Species composition of phytophages and entomophages in the lower reaches of the Zarafshan river.

\begin{tabular}{|c|c|c|c|}
\hline $\begin{array}{c}\text { Detachment } \\
\text { unit }\end{array}$ & Family & Genus, species & $\begin{array}{c}\text { Prevalence } \\
+++ \text { - main } \\
\text { (numerous) types } \\
++- \text { common types } \\
+ \text { - single species }\end{array}$ \\
\hline \multicolumn{2}{|c|}{} & \multicolumn{2}{|c|}{} \\
\hline Acariformes & Tetranychidae & P H Y T O P H A G E S & +++ \\
\cline { 3 - 4 } & & Tetranihus & \\
\hline Ortoptera & Tettigonidae & 1.T.urticae Koch. & Tettigonia \\
\hline
\end{tabular}




\begin{tabular}{|c|c|c|c|}
\hline $\begin{array}{c}\text { Detachment } \\
\text { unit }\end{array}$ & Family & Genus, species & \begin{tabular}{l}
\multicolumn{1}{c}{$\begin{array}{c}\text { Prevalence } \\
+++ \\
\text { (numerous) }\end{array}$} \\
++ - common types \\
+ - single species
\end{tabular} \\
\hline & & 2.T.viridissima L. & ++ \\
\hline & \multirow[t]{2}{*}{ Gryllidae } & Gryllus (Melanogryllus) & \\
\hline & & 3.G.desertus Fall. & + \\
\hline & \multirow[t]{2}{*}{ Gryllotalpidae } & Gryllotalpa & \\
\hline & & 4.G.unispina Saw. & + \\
\hline & \multirow[t]{6}{*}{ Acrididae } & Calliptamus & \\
\hline & & 5.C.italicus italicus L. & ++ \\
\hline & & Dociostaurus (S.Str.) & \\
\hline & & 6.D.moroccans Thunb. & ++ \\
\hline & & Locusta & \\
\hline & & 7.L.migratoria migratoriya L. & + \\
\hline \multirow[t]{21}{*}{ Homoptera } & \multirow[t]{2}{*}{ Cicadidae } & Gucadatra & \\
\hline & & 8.G.ochreata Mel. & ++ \\
\hline & \multirow[t]{6}{*}{ Cicadellidae } & Austroagalia & \\
\hline & & 9.A.sinuata M.R. & + \\
\hline & & Kyboasca & \\
\hline & & 10.K.bipunctata Osh. & +++ \\
\hline & & Bemisia & \\
\hline & & 11.B.tabaci Genn & ++ \\
\hline & \multirow[t]{13}{*}{ Aphididae } & Aphis & \\
\hline & & 12.A.craccivora Koch. & +++ \\
\hline & & 13.A.gossypii Glov. & +++ \\
\hline & & Acyrthosiphon & \\
\hline & & 14.Ac.gossypii Mordv. & +++ \\
\hline & & Brachyunguis & \\
\hline & & 15.Br.plotnikovi Das. & ++ \\
\hline & & Myzodes & \\
\hline & & 16 M.percicae Sulz. & + \\
\hline & & Therioaphis & \\
\hline & & 17.Th.trifolii Men. & ++ \\
\hline & & Smynthurodes & \\
\hline & & 18.Sm.betae Westw. & + \\
\hline \multirow[t]{7}{*}{ Hemiptera } & \multirow[t]{2}{*}{ Peptatomidae } & Acrosternum & \\
\hline & & 19.Ac.breviceps Jak. & ++ \\
\hline & \multirow[t]{5}{*}{ Miridae } & Adelphocoris & \\
\hline & & 20.Ad.lineolatus Goeze. & ++ \\
\hline & & Lygus & \\
\hline & & 21.L.Peatensis L. & +++ \\
\hline & & 22.L.gemeleatus L. & +++ \\
\hline \multirow[t]{2}{*}{ Thysonoptera } & \multirow[t]{2}{*}{ Thripidae } & Thrips & \\
\hline & & 23.T.tabaci Lind. & ++ \\
\hline \multirow[t]{4}{*}{ Coleoptera } & \multirow[t]{2}{*}{ Elateridae } & Agriotes & \\
\hline & & 24.Ag.meticulosus Cand. & + \\
\hline & \multirow[t]{2}{*}{ Tenebrionidae } & Dialognata & \\
\hline & & 25.D.nasuta Men. & ++ \\
\hline
\end{tabular}




\begin{tabular}{|c|c|c|c|}
\hline $\begin{array}{l}\text { Detachment } \\
\text { unit }\end{array}$ & Family & Genus, species & $\begin{array}{l}\quad \text { Prevalence } \\
+++ \text { - main } \\
\text { (numerous) types } \\
++ \text { - common types } \\
+ \text { - single species }\end{array}$ \\
\hline & & Gonocephalus & \\
\hline & & 26.G.pusillus Fabr. & + \\
\hline & & Opatroides & \\
\hline & & 27.Op.punctulatus Brull. & + \\
\hline \multirow[t]{7}{*}{ Lepidoptera } & \multirow[t]{7}{*}{ Noctuidae } & Agrotes & \\
\hline & & 28.A.segetum Den.et.Schiff. & ++ \\
\hline & & 29.A.exclamationis L. & ++ \\
\hline & & Helicoverpa & \\
\hline & & 30.H.armigera Hbn. & +++ \\
\hline & & Syndrapha & \\
\hline & & 31.S.circumflexa L. & + \\
\hline \multicolumn{4}{|c|}{ EN T O MOP H A GES } \\
\hline \multirow[t]{11}{*}{ Hemiptera } & \multirow[t]{3}{*}{ Anthocoridae } & Orius & \\
\hline & & 1.O.niger Wolf. & ++ \\
\hline & & 2.O.albidipennis Reut. & + \\
\hline & \multirow[t]{2}{*}{ Meredae } & Camptobrochis & \\
\hline & & 3.Cam.punctulatus Schill. & ++ \\
\hline & \multirow[t]{2}{*}{ Nabidae } & Nabis & \\
\hline & & 4.N.ferus L. & ++ \\
\hline & \multirow[t]{2}{*}{ Lygaedae } & Geocoris & \\
\hline & & 5.G.lapponicus Fell. & + \\
\hline & \multirow[t]{2}{*}{ Thysonoptera } & Scolothrips & \\
\hline & & 6.Sc.acariphagus Jakh. & +++ \\
\hline \multirow[t]{12}{*}{ Coleoptera } & \multirow[t]{12}{*}{ Coccinellidae } & Coccinella & \\
\hline & & 7.C.septempunctata L. & +++ \\
\hline & & 8.C.conglabata L. & ++ \\
\hline & & 9.C.undecimpunctata L. & ++ \\
\hline & & Propylea & \\
\hline & & 10.P.guatuordecimpunctata L. & ++ \\
\hline & & Adonia & \\
\hline & & 11.A.variegata Gz. & + \\
\hline & & Scymnus & \\
\hline & & 12.S.frobtalis Forb. & + \\
\hline & & Stethorus & \\
\hline & & 13.St.punctillum Wse. & +++ \\
\hline \multirow[t]{4}{*}{ Neuroptera } & \multirow[t]{4}{*}{ Chrysopidae } & Chrysopa & \\
\hline & & 14.Ch.carnea Steph. & +++ \\
\hline & & 15.Ch.septempunctata Wesm. & ++ \\
\hline & & 16.Ch.olboleneata Kill. & + \\
\hline \multirow[t]{6}{*}{ Hymenoptera } & \multirow[t]{4}{*}{ Ichneumonidae } & Barylipa & \\
\hline & & 17.B.amablilis Tosquinet. & + \\
\hline & & Heposeter & \\
\hline & & 18.H.didimator Tunb. & + \\
\hline & \multirow[t]{2}{*}{ Braconidae } & Bracon & \\
\hline & & 19.B.hebetor Say. & +++ \\
\hline
\end{tabular}




\begin{tabular}{|c|c|c|c|}
\hline $\begin{array}{c}\text { Detachment } \\
\text { unit }\end{array}$ & Family & Genus, species & \begin{tabular}{l}
\multicolumn{1}{c}{ Prevalence } \\
+++ - main \\
(numerous) types \\
++ - common types \\
+ - single species
\end{tabular} \\
\hline \multicolumn{4}{|c|}{ Apanteles } \\
\hline & & 20.A.kasak Tel. & ++ \\
\hline & \multirow[t]{2}{*}{ Vespidae } & Vespa & \\
\hline & & 21.V.orientales F. & + \\
\hline & \multirow[t]{7}{*}{ Aphidiidae } & Aphidius & \\
\hline & & 22.A.ervi Hab. & ++ \\
\hline & & 23.A.fabarum March. & ++ \\
\hline & & Praon & \\
\hline & & 24.P.dorsale Hol. & + \\
\hline & & Diaeretiella & \\
\hline & & 25.D.rapae M.Intoch. & + \\
\hline & \multirow[t]{2}{*}{ Formicidae } & Formica & \\
\hline & & 26.F.subpilosa Rurs. & \\
\hline \multirow[t]{10}{*}{ Diptera } & \multirow[t]{10}{*}{ Syrphidae } & Syrphus & \\
\hline & & 27.S.vitripennis Mg.S. & + \\
\hline & & 28.S.interrumpens Wek. & + \\
\hline & & 29.S.coroliae F. & +++ \\
\hline & & Sphaerophoria & \\
\hline & & 30.Sph.rueppelli Wied. & + \\
\hline & & Scaeva & \\
\hline & & 31.Sc.albomaculata Meg. & ++ \\
\hline & & Paragus & \\
\hline & & 32.P.aegyptius Mg. & + \\
\hline
\end{tabular}

The most widespread phytophages are Tetranichus urticae, Helicoverpa armigera, Aphis craccivora, A.gossypii, Acyrthosiphon gossypii. We attribute them, according to the system of F.M. Uspenskiy [7], to numerous species, which, in the lower reaches of the Zarafshan River, are the main phytophages that cause significant damage to crop production, in particular to cotton. The identified phytophages are included in 7 orders, 14 families and 28 genera. The most numerous phytophagous species is the Ortoptera order, which includes 4 families, 6 genera and 6 species. The order Homoptera includes 3 families, 10 genera and 11 species. The remaining orders are somewhat inferior to the previous ones in terms of the quantitative composition of taxonomic units.

\section{Findings}

Under conditions of anthropogenic impact, certain changes took place among phytophages. Thus, the construction of the Amu-Karakul and Amu-Bukhara canals contributed to the increase in the spread of the cotton bollworm. Previously, numerous species of Kyboasca bipunctata, especially Lygus pratensis and Lygus gemeleatus, are now widely represented due to the development of new lands for cotton and other agricultural crops. Meanwhile, numerous species of phytophages (Euxoa agricola, Spodoptera exigua) previously identified here by a number of authors $[2,8,11]$ were absent in our materials. Some of the species noted by us are classified as potential phytophages (Acrosternum breviceps, Agrotes txclamationis, Dialognata nasuta), which, when the necessary conditions for their life are created, can take a place among the main phytophages of the lower reaches of the Zarafshan river. 
Among entomophages, according to the qualitative diversity of taxa, we distinguished the order Hymenoptera, consisting of 5 families, 8 genera, and 10 species, as well as the Coccinellidae family (order Coleoptera), which includes 5 genera and 7 species. The main entomophages are represented by 6 species (Scolothrips acariphagus, Coccinella septempunctata, Stethorus punctillum, Chrysopa carnea, Bracon hebetor, Serphus coroliae), which are widespread.

\section{References}

1. R.A. Alimjanov, Formation of harmful entomofauna of cotton and alfalfa in the Karshi steppe (Fan, Tashkent, 1974)

2. A.Sh. Khamraev, All-Union. conf. on the ecology of aphids. Andijan, 64-66 (1991)

3. Sh.T.Khojaev, Modern methods and means of integrated plant protection against pests (Tashkent, 2015)

4. V.V. Yakhontov, List of pests of agricultural plants of the Bukhara district and registered predators and parasites. (Shirobudinskaya experimental agricultural station, Tashkent, 1929).

5. N.N. Bogdanov-Katkov, Entomological excursions to vegetable fields and orchards (Selkhozgiz, Moscow, 1934)

6. M.S. Gilyarov, Pochvovedenie, 4., 48-77 (1941).

7. F.M. Uspenskiy, Methodology of field and vegetation experiments with cotton, 162-175 (SoyuzNIHI, Tashkent, 1973)

8. K.I. Larchenko, Ecology of the cotton bollworm and the timing of its control Fan, Tashkent, 1968)

9. S.N. Alimehamedov, Seminar on the economic thresholds of harmfulness of cotton pests and the prospects for biological control methods, 17-21 (Tashkent, 1979)

10. Ts.G. Bracket, Questions of plant protection, 7-19 (Fan, Tashkent, 1967)

11. A.Sh. Khamraev, Entomocomplexes of cotton agrobiocenosis (phytophages, entomophages), the formation, functioning and improvement of the biological bases of their regulation: Abstract of the thesis. Doctor of Biological Sciences (Tashkent, 1992) 